\title{
Useable pasts for a cooperative university: as different as light from darkness?
}

\section{Tom Woodin}

Higher education has been a troubling presence for the consumer co-operative movement throughout its history. The university held a fascination for co-operators whose plans for a co-operative commonwealth encapsulated a wide range of dreams and desires. Co-operatives contributed British universities by developing close working relations with academic staff and this stimulated curricula and organisational innovation. Although some co-operators eschewed the snobbery of universities, which felt like a different world from everyday working class life, this reaction could also generate new educational ideas. For instance, the movement established its own initiatives in higher learning based upon the unique nature of co-operatives.

The renewed interest in the co-operative university has been a stimulant for historical exploration and the recovery of 'useable pasts' to illuminate new perspectives on the present. Such an exploration offers a means of historicising present-day projects that may have deeper historical roots than first appearances would suggest. Long-term historical trends infuse debates among proponents of the co-operative university and a recent conference on the subject unearthed myriad historical references. ${ }^{1}$ This approach reflects a growing trend among historians to critically examine the contemporary significance of the past. ${ }^{2}$ Indeed, an understanding of previous co-operative educational initiatives can inform the co-operative university today.

Historically, 'higher education' and 'university' have proved to be slippery concepts that elude clear cut definitions because they have been imbricated within social and political change. Recent decades have witnessed a narrowing of the parameters of higher education

\footnotetext{
${ }^{1}$ Voinea, Anca. 2017. Setting a vision a co-operative university. Co-operative News, November 27. https://www.thenews.coop/124550/topic/setting-vision-co-operativeuniversity/ Accessed November 202018.

2 Tosh, John. 2008. Why history matters. Basingstoke: Palgrave Macmillan. See also History and Policy Website, http://www.historyandpolicy.org/ Accessed December 15 2018. Woodin, Tom, McCulloch Gary and Cowan, Steve. 2013. Secondary education and the raising of the school leaving age: Coming of age? New York: Palgrave Macmillan.
} 
and the dominance of one notion of the university. ${ }^{3}$ The fluid meaning of tertiary education, which once encompassed colleges of higher education, polytechnics and training institutes, has given way to a hierarchy of universities which struggle for position in an unequal market. ${ }^{4}$ Yet rapid social change has stimulated widespread debate over the nature of the university ${ }^{5}$ which continues to be marked by considerable complexity. ${ }^{6}$ In the past, the educational hierarchies and disciplinary boundaries of the university were thorny issues for co-operators. ${ }^{7}$ Marginal and adult education movements have long struggled with 'higher' education, standards and quality. For example, prior to the onset of secondary education for all, following the 1944 Education Act, 'higher' often referred to any form of post-elementary education. W. R. Rae, who chaired the Co-operative Union Central Education Committee, referred to 'secondary, or higher education work', recognising that secondary and university education were both well out of reach for most working class families. ${ }^{8}$

While the idea of a co-operative university has a long pedigree stretching back into the nineteenth century, recent social changes have helped to make it a realistic possibility. ${ }^{9}$ Dan Cook suggested three methods of creating a co-operative university: to reorganise part of a university into a co-operative that might involve a department or faculty working cooperatively; to transform an existing university into a co-operative in which stakeholder

\footnotetext{
${ }^{3}$ Shattock, Michael. 2012. Making policy in British higher education, 1945-2011. Maidenhead: Open University Press; Shattock, Michael. 2014. University governance in the UK: bending the traditional model. In International trends in university governance: Autonomy, self-government and the distribution of authority, ed. Michael Shattock, 127-44. London: Routledge.

${ }^{4}$ Woodin, Tom. 2018. Co-operative approaches to leading and learning: Ideas for innovation from the UK and beyond. In Exploring consensual leadership in higher education: Cooperation, collaboration and partnership, ed. Lynne Gornall, Brychan Thomas and Lucy Sweetman, 71-88. London: Bloomsbury.

${ }^{5}$ McGettigan, Andrew. 2013. The great university gamble: Money, markets and the future of higher education. London: Pluto; Yeo, Stephen. (2015) The co-operative university? Transforming higher education. In Co-operation, Learning and Co-operative Values, ed, Tom Woodin, 131-46. London: Routledge; Neary, Mike. and Winn, Joss. 2017. Beyond public and private: A framework for co-operative higher education. Open Library of Humanities 3, 2: 1-36; Collini, Stefan. 2017. Speaking of Universities. London: Verso. ${ }^{6}$ Barnett, Ronald. 2016. Understanding the university: institution, idea, possibility. London: Routledge.

${ }^{7}$ Woodin, Tom and Shaw, Linda. 2019 in press. Learning for a co-operative world: education, social change and the Co-operative College. London: Trentham/UCL Press. ${ }^{8}$ Rae, W. R. 1921. P7 ${ }^{9}$ Neary, Mike and Winn, Joss. 2019 in press. The co-operative university now! In Woodin and Shaw, Learning for a co-operative world...
} 
groups might share governance; and to create a new university. ${ }^{10} \mathrm{~A}$ further concern has been to integrate the study of, and teaching about, co-operatives into the curriculum of universities, nesting 'co-operative studies' within and between the dominant disciplinary boundaries of higher education. ${ }^{11}$ An opportunity arose with the 2017 Higher Education Act which is attempting to 'open up' higher education by allowing a range of providers to apply for degree-awarding powers. The co-operative university has been one of the unexpected front runners in this game. It promises a new form of higher education but also raises problematic issues for co-operatives and co-operators. ${ }^{12}$ It appeals to the Statement on Co-operative Identity of the International Co-operative Alliance (ICA) which includes values of democracy, equality, equity, solidarity, self-help and self-responsibility while the principles emphasise democratic control by members. ${ }^{13}$ The definitions leave a lot of scope for the ways in which the values and principles will be applied in practice. They also help us to chart historical patterns which reverberate today.

\section{Utopian visions?}

From the inception of the co-operative movement, educational initiatives were viewed as central to the success of the movement. In the early nineteenth century, radicals problematised emerging capitalist relations that were displacing older assumptions about work, welfare and family and it was hoped that more supportive alternatives could be built. Education was viewed as essential to any future state of society. For instance, partly under the influence of Robert Owen and Owenism, the Rochdale Pioneers aimed to 'arrange the powers of production, distribution, education and government, or in other words, to establish a self-supporting home colony of united interests, or assist other societies in establishing such

${ }^{10}$ Cook, Dan. 2013. Realising the co-operative university: A consultancy report for the Cooperative College. Manchester: Co-operative College.

${ }^{11}$ MacPherson, Ian and Mclaughlin-Jenkins, Erin, eds. 2008. Integrating diversities within a complex heritage: Essays in the field of co-operative studies. Victoria: New Rochdale Press; MacPherson, Ian. 2015. Mainstreaming some lacunae: Developing co-operative studies as an interdisciplinary, international field of enquiry. In Co-operation, learning and co-operative values, ed. Tom Woodin, 177-94. London: Routledge.

${ }^{12}$ Ross, Cilla, Winn, Joss, Neary, Mike and Parkinson, Simon. 2017. Co-operative universities: a chance to reimagine higher education?' Co-operative Party blog, https://party.coop/2016/09/01/co-operative-universities-time-for-a-radical-re-think-of-highereducation/ Accessed 20 June 2017.

${ }^{13}$ ICA. 2018. Statement on co-operative identity. https://www.ica.coop/en/cooperatives/cooperative-identity Accessed November 202018. 
colonies. ${ }^{, 14}$ Education was considered one of four fundamental areas of a social system and was mutually interdependent with government, production and distribution.

Given the concern for widespread change, it is unsurprising to find that calls for a cooperative university and college continue to flicker in the imagination of early and midnineteenth century co-operators who invoked the 'universal' implications inherent in the idea of a university. ${ }^{15}$ In his history of co-operative education, H. J. Twigg reported the desire for a 'school or college' for co-operators that was proposed by Charles Fry of the Liverpool Cooperative Wholesale Purchasing Agency in $1830 .{ }^{16}$ Similar impulses arose from the Cooperator in Brighton organised by Dr William King as they did elsewhere around the country. ${ }^{17}$

The desire for education and learning also implied transformation rather than simple extension. ${ }^{18}$ The Owenite Henry Travis was convinced that co-operative education should be 'as different from the system of education hitherto practised, as the Economics of the Cooperative System are from those of the competitive state of things, and as light is from darkness....${ }^{19}$ Early nineteenth century radicals worked at a time when industrial capitalism was only partly established and compulsory schooling and age grading had not been set in stone. Good childhood education was a prerequisite and Robert Owen's pioneering nursery school at New Lanark would be an important example of this. Yet education was conceived as more of a continuous process that blurred the distinctions between ages and levels. Rather Owenites highlighted the connections across the lifecourse and the potential solidarities in a mutual movement, evident in the names of initiatives such as the Association of All Classes of All Nations that aspired to embrace everything. ${ }^{20}$

\footnotetext{
${ }^{14}$ Rochdale Pioneers. 1844. Law the first. See https://www.rochdalepioneersmuseum.coop/about-us/1844-rule-book/ Accessed October 20 2018.

${ }^{15}$ Woodin, Co-operative approaches...

16 Twigg, H. J. 1924. An outline history of co-operative education. Manchester: Co-operative Union.

${ }^{17}$ Mercer, Thomas W. 1947. Co-operation's prophet: The life and letters of Dr. William King of Brighton. Manchester: Co-operative Union.

${ }^{18}$ Williams, Raymond 1965. The long revolution. Harmondsworth: Penguin.

19 Travis, Henry. 1871. The co-operative system according to Robert Owen, with the fundamental correction which it requires, Co-operative congress 1871, Birmingham p83. Manchester: Co-operative Union.

${ }^{20}$ Johnson, Richard. 1979. 'Really useful knowledge': radical education and working class culture, 1790-1848. In Working class culture: Studies in history and theory, eds., Clarke, John, Critcher, John and Johnson, Richard, 75-102. London: Hutchinson; Yeo, Stephen.
} 
An additional element of early co-operation related more directly to the nature of knowledge. A key feature of Owenite 'social science' was to reincorporate the moral realm which had been drained from the 'dismal science' of political economy. ${ }^{21}$ In 1863, George Vasey addressed a co-operative tea party in Eston, Yorkshire where he prioritised the need for physical comforts and welfare but held that there should be a simultaneous education along moral and spiritual lines

the glorious principles of Co-operation must inevitably ascend through every grade of moral, intellectual, and spiritual progress, until it reaches the highest state of elevation and refinement of which humanity is susceptible. ${ }^{22}$

Education implied a process without limits. Alongside the moral and spiritual sphere, cooperators aimed to integrate vocational and liberal ideas of learning. The Owenite, William Pare, recommended the construction of 'industrial colleges' in collaboration with new communities and 'associated homes' where children of both sexes would be sent 'for training in really good and virtuous habits, and instruction ... not only in literary and scientific pursuits, according the ordinary scholastic routine, but in useful trades and occupations, by which they might be fitted at maturity for a far higher sphere of usefulness and happiness than that filled or enjoyed by any class of society at present'. ${ }^{23}$ Indeed, Pare envisaged that education would improve upon any known system of education and provide 'a better knowledge of science and art that do now the children of the middle and upper classes... ${ }^{24}$ The co-operative movement would continue to be marked by the repeated effervescence of utopian and Owenite philosophies. ${ }^{25}$ Utopianism arose directly out of the attempt to build the new moral world in the here and now. It infused daily organising with a wider purpose, that it

2010. Education for association: Re-membering for a new moral world. In Derrick, Jay et al. Remaking Adult Learning. London: Institute of Education and NIACE; also E. P. Thompson. 1968. The making of the English working class. Harmondsworth: Penguin.

${ }^{21}$ Janes Yeo, Eileen. 1996. The contest for social science: relations and representations of gender and class. London: Rivers Oram Press.

${ }^{22}$ Vasey, George. 1863. Quoted in The Co-operator July, 24.

${ }^{23}$ Pare, William. 1871. Co-operative industrial colleges combined with agriculture and manufactures, Co-operative congress 1871, Birmingham, 40.

${ }^{24}$ Ibid., 43.

${ }^{25}$ Compare, Pollard, Sidney. 1961. Nineteenth century co-operation: from community building to shopkeeping. In Essays in labour history, eds., Briggs, Asa and Saville, John, 74112. London: Macmillan. 
was contributing to a 'peaceful revolution' ${ }^{26}$ which would encroach upon and ultimately alter profoundly the nature of higher education. The ubiquitous and all-enveloping conception of education nurtured the idea of the co-operative commonwealth which necessarily embraced all forms of education: in 1919 co-operators were still arguing that, 'Co-operation is a mode of life; a vital principle which we desire to see adopted in every phase of social life', ${ }^{27}$

\section{University extension and worker's universities?}

The persistent strand of utopianism was in part facilitated by the extraordinary growth of consumer co-operatives from the mid-century point. Co-operators at Rochdale and elsewhere were keen to gain knowledge at a moment when the ancient universities were seen as out of touch with social changes. One outcome was the university extension movement. It facilitated lecture tours, particularly of northern industrial areas, by university staff and attracted co-operators as well as many women. The Rochdale Pioneers, looking for ways to use the $2 \frac{1}{2} \%$ of profits that they devoted to education, requested lectures. James Stuart, widely credited as the key figure in the emergence of university extension, averred that the idea of having a class in connection with university extension originated with the Pioneers and its inquisitive members who were of 'high views and exalted principles'. ${ }^{28}$ Stuart was so impressed by the Rochdale society that he urged societies to "take the lead, to engage a group of teachers of the highest class, and to utilise these as peripatetic professors of a Co-operative University' which might be extended on a 'national basis' ${ }^{29}$ The Pioneers would be one of four organisations to write a memorial in support of university extension.

Co-operators were incredibly interested in political and social changes. Their interaction with the ancient universities would be an issue at the heart of the emergence of democracy in Britain and beyond. The incremental extension of the franchise to working people gave rise to much debate. The expansion of democracy involved a new approach to civil society which affected all major institutions. Although the 1867 Reform Act was limited in its scope, it symbolised the inclusion of working men in the nation and empire which generated both

\footnotetext{
${ }^{26}$ Webb, Catherine. 1921. Industrial co-operation: The story of a peaceful revolution. Manchester: Co-operative Union.

${ }^{27}$ Hayward, Fred. Inaugural address. Co-operative congress 1919, 96. Manchester: Cooperative Union.

${ }^{28}$ Stuart, James. 1911. Reminiscences. London: Chiswick Press, 165.

${ }^{29}$ Ibid., 167, 169.
} 
hope and fear. To the middle classes, co-operatives provided reassuring evidence of responsibility, character and improvement among enfranchised groups. In appealing to these audiences on the eve of the Reform Bill, Lloyd Jones and J.M. Ludlow wrote about the 'progress' of the working class. They affirmed that 'No form of association ... proves so much in favour of the moral and intellectual progress of the working people as Cooperation.' ${ }^{30}$ It was hoped that giving the working classes responsibilities would help to align them with nation and Empire. For instance, Hudson Shaw, a prolific extension lecturer, explicitly grouped these strands together in an address to co-operators: 'The future of our country is in the hands of the working class; upon their wisdom and knowledge and patriotism the vastest Empire the world has known ... rests for its safety and continuance'. ${ }^{31}$ He viewed co-operatives as key agencies in forging citizenship

In alliance with the Universities we can cover half of England in a few years with a network of teaching centres, where every Englishman may study his own national record: the deep questions of history which underlie the problems of to-day; the principles of good government and successful rule; the whole philosophy of national well-being; the best that has been thought and said upon the possibilities of human life on this planet. $^{32}$

University extension lecturers found willing audiences among co-operative societies. Hudson Shaw considered the involvement of co-operative societies to be crucial to the success of lectures which facilitated direct contact with working people. ${ }^{33}$ In addition, Oxford summer schools made space for co-operators where new ideas gestated and were ideal for 'bringing co-operators into touch with the higher phases of educational developments... 34

\footnotetext{
${ }^{30}$ J.M. Ludlow, John M. and Jones, Lloyd. 1867. The progress of the working classes. In Questions for a reformed parliament, 278. London: Macmillan and co.

${ }^{31}$ Hudson Shaw, W. nd. Co-operation and education: To the working men co-operators of Great Britain, 8. Manchester: Co-operative Union.

${ }^{32}$ Ibid., 9-10.

${ }^{33}$ Ibid., 9. Also, Co-operative Union. 1898. Report of Central Board, Co-operative congress 1898, Peterborough, 16. Manchester: Co-operative Union.

${ }^{34}$ Co-operative Union. 1898. Report of Central Board, Co-operative congress 1898, 15. Manchester: Co-operative Union.
} 
University extension gave rise to interesting and intense relationships which belies the claim that it simply represented a form of class control. ${ }^{35}$ Mutual learning between lecturer and audience could be significant. Yet even though co-operation brought people together, cooperators were wary of those who viewed the movement as a place where other agendas could be pursued, a feeling heightened by the fact that, formally, the universities retained control of the educational process. As a result, there were class tensions over how vibrant democratic aspirations were to be met. It mirrored class discord within the co-operative movement between idealists and Christian Socialists, who supported co-operation while attempting to channel it in certain directions, and working class co-operators who were cautious about being co-opted to ulterior purposes. In the early 1880 s, the co-operator, Ben Jones resisted the injunctions of liberal politician and educationist A. H. D. Acland and the campaigner and historian, Arnold Toynbee, who spoke about the education of the citizen in a way which Jones feared might squeeze out the specific needs of co-operators:

They were not going to do the bidding of university dons, but think for themselves, develop their own faculties, and instruct their members and children in a thorough knowledge of the principles of co-operation. They must not overshoot the mark in aiming at a university. The kernel of the system must be education in co-operation. ${ }^{36}$

Being in awe of the university might divert co-operators from their core purpose which, in educational terms, was to cultivate what became known as 'co-operative character' based upon mutual working relationships and co-operative understanding. Yet, such friction could be channeled in productive ways and Jones would collaborate with Acland on a handbook, first published in 1884, Working men co-operators. ${ }^{37}$ Nonetheless, the memory and legacy of key middle class figures who had helped the movement immensely carried ambiguous feelings. In 1921, Rae recalled that

Christian Socialists such as EV Neale and Thomas Hughes set up scholarships in their names so that children of co-operators could study at Oxbridge. Over time, it was

\footnotetext{
${ }^{35}$ Rowbotham, Sheila. 1999. Travellers in a strange country: Responses of working class students to the University Extension Movement 1873-1910. In Rowbotham, Sheila, Threads through time, 260-301. London: Penguin. Goldman, Lawrence. 1995. Dons and workers. Oxford and adult education since 1850. Oxford: Clarendon Press.

${ }^{36}$ Jones, Ben. 1883. Contribution to Co-operative Congress 1883, 40. Manchester: Cooperative Union.

${ }^{37}$ Acland, Arthur Herbert Dyke and Jones, Ben. 1884. Working men co-operators. Manchester: Co-operative Union.
} 
argued that such schemes did not serve the movement well but rather acted as ladders of social mobility into the middle class rather than ways of strengthening the movement. ${ }^{38}$

Rae argued that the Oxbridge syllabus took scholars from working families and 'dragged them out of their class and filled them with a desire to earn their living with their pens or by preaching. ${ }^{39}$ Co-operatives were tied in with a tradition of adult and radical education which aimed to improve people and communities not simply foster social mobility, an argument which has a familiar contemporary resonance. Individual improvement had to be tied into collective gains and the gradual extension of the co-operative commonwealth. R. H. Tawney's had also encouraged co-operative societies to involve themselves in higher education and related ideas about social mobility would appear in his classic 1931 book, Equality.

\section{Workers' education}

In the early twentieth century, similar contradictions were to feed into the emergence of the Workers' Educational Association (WEA) and university tutorial classes. Once again, the cooperative movement was in the midst of the action although it was to become more marginalised over time. Albert Mansbridge, widely credited as the founder of the WEA, writing in the Kingdom of the Mind, affirmed that university extension and the co-operative movement were the two significant educational forces for adults:

University Extension ... has recognised to the full democratic needs, and has consistently rendered its high teaching acceptable to working men. On the other hand, the Co-operative movement has rendered to education ... a greater measure of tribute than any other democratic movement. It has ... set upon foot a system of class teaching in industrial history, economics, and citizenship. Moreover, it has entered already into a working alliance with University Extension. ${ }^{40}$

\footnotetext{
${ }^{38}$ Rae, W. R. 1921. 7.

${ }^{39}$ Rae, W. R. 1911. Contribution to Co-operative congress 1911, 523. Manchester: Cooperative Union.

${ }^{40}$ Mansbridge, Kingdom, 4.
} 
The great skill of Mansbridge was that he fused 'the ideals of the Co-operative and Trade Union movements with those of the universities. ${ }^{41} \mathrm{He}$ built bridges across the languages of co-operation, social class, citizenship, social purpose and Christianity. By blending working class control with the priorities of the universities, Mansbridge managed to bring together traditions that were ostensibly in the same family but were constantly bickering. Idealist philosophers, Christian socialists and Fabians, while celebrating the progress of the working class, could be critical of what they perceived to be the pure materialism and earthiness of the working class who they portrayed as too focused upon the living wage, the dividend and basic necessities of life. ${ }^{42}$ Conversely, co-operators had been critical of the middle classes who interfered and tampered with their democratic movements while demanding devotion to an intangible higher spirit. Mansbridge was fluent in both languages. He adeptly handled class suspicions and chided co-operators for 'an unpardonable suspicion of the university, often flavoured with contempt, and a pronounced antipathy to anything that can possibly be misconstrued into a desire on the part of any movement, educational or otherwise, pushing its own legitimate work, to exploit them' ${ }^{43}$ Co-operators could indeed have an adverse reaction to purveyors of theoretical ideas which could not be put to immediate use.

Yet, Mansbridge would not settle for second best and was critical of elementary education which only placed a veneer of knowledge upon the young mind and instead he called for deeper meaningful learning. He argued that the 'idea of a gospel of education' was familiar to working class people and that the ideas of the co-operative movement have been 'shot through and through with educational desire', which revealed his appreciation of the utopian aspect of co-operation and an unfulfilled longing which latched onto the potential for an educated society. ${ }^{44} \mathrm{He}$ grasped the fact that workers had not taken kindly to top-down

${ }^{41}$ Clark, Leonard. 1946. Introduction. In Clark, The kingdom of the mind: Essays and addresses of Albert Mansbridge, xi-xii. Manchester: Meridian.

${ }^{42}$ Yeo, Stephen. 1987. Three socialisms: statism, collectivism, associationism. In Social Criticism and Social Theory, eds. Outhwaite, William and Mulkay, Michael, 83-113. Oxford: Blackwell; Gurney, Peter. 1996. Co-operative culture and the politics of consumption in England 1870-1930. Manchester: Manchester University Press; Woodin, Tom. 2011. Cooperative education in the nineteenth and early twentieth centuries: context, identity and learning. In Webster, Anthony et al, The hidden alternative: Co-operative values, past, present and future, 78-95. Manchester: Manchester University Press and United Nations University Press.

${ }^{43}$ Mansbridge, Albert. 1946. Co-operation, trade unionism, university extension. In Clark, Kingdom of the mind, 5-6.

${ }^{44}$ Mansbridge, Adventure ..., xviii 
educational schemes and it was the co-operative movement that provided him with the model for a new type of workers' university

Everything pointed to the fact that educational supply, even if devised by excellent and devoted people, was almost entirely useless unless there was co-operation with those who were to be attracted to use it. In the development of working class education the scholar and administrator must sit side by side with the adult student, at the same table, in perfect freedom. The initiative must lie with the students. They must say how, why, what, or when they wish to study. It is the business of their colleagues the scholars and administrators to help them to obtain the satisfaction of their desires. This means that scholar, administrator, and working man must act together, and fortunately there are, and always have been in England, many organisations of labour and scholarship in a mood to do so in their corporate capacity. ${ }^{45}$

Co-operative desire and democracy were crucial ingredients in the construction of Mansbridge's educational network. Yet it was to have mixed blessings for the co-operative movement which did not always reap the rewards of such innovation. For instance, a survey of the co-operative movement during the First World War reflected ruefully that 'educational zeal', which should rightfully be retained by the co-operative movement, was finding other outlets. ${ }^{46}$ Once again, co-operators would look to themselves for educational growth.

\section{The Co-operative College}

From the late nineteenth century, there had been increasing calls for a co-operative university that would eventuate with the formation of the Co-operative College in $1919 .{ }^{47}$ In the $1870 \mathrm{~s}$, Nicholas Baline, a Russian co-operator, had called for a co-operative university to enable the movement, including women, to respond to social changes. By the early twentieth century, calls for action were intensifying and both Edward Owen Greening and W.R. Rae would advocate a co-operative university. Co-operators also attended meetings with universities and

\footnotetext{
45 Ibid., xviii

${ }^{46}$ See Co-operative Union. 1919. Appendix, General Co-operative Survey. Manchester: Cooperative Union.

${ }^{47}$ See Woodin, Tom, Vernon, Keith and Shaw, Linda. 2019 forthcoming. The Co-operative College and a century of social change. London: Palgrave.
} 
the 1910 Congress passed a resolution that universities should 'become national institutions equally in touch with all sections of the community'. ${ }^{48}$ The following year, a co-operative deputation met with the President of the Board of Education, Walter Runciman MP, when they argued that the free universities, such as Victoria, were too much under the influence of commercial classes whereas the ancient universities were in need of 'democratisation' whereby all social classes would play a role in their administration. Adding her influential voice was Margaret Macmillan who called on the movement to create a 'great rural cooperative university' where the 'best scholars' would be 'willing and able to support you' and she speculated that such a move would 'go far to change the whole future of England'. ${ }^{49}$

The Co-operative College was to be a higher form of education for the movement that embraced teaching, research and promotion of co-operatives. The movement was facing intense commercial competition and political attacks. The president of the 1918 Co-operative Congress, Thomas Killon, observed that new forms of co-operation represented by business trusts and state action were significant threats, 'our principle has been stolen to bolster up vested interests ... ${ }^{50}$ Part of the answer lay in the formation of the Co-operative Party as well as new educational initiatives: 'If we are to make co-operation not merely part of the State, or a State within a State, but the State itself, we shall require the highest education... ${ }^{51}$ Fred Hall, the first principal of the College, argued that the relationship of the proposed college to the universities had not been properly thought out but it was being proposed because 'the other colleges did not approach education from the same point of view as co-operators did' ${ }^{52}$ In forming the College, they were 'endeavouring to build up a complete system of education for co-operators' 53 and to direct the 'educational machinery' of the movement as a whole.

\footnotetext{
${ }^{48}$ Baline, Nicholas. 1872. Propaganda: A suggestion for a co-operative university. In Cooperative Congress 1872, 80. Manchester: Co-operative Union; Greening, Edward Owen. 1904. Inaugural address. Co-operative Congress 1904, 41-3. Manchester: Co-operative Congress; Rae, W. R. 1911. Inaugural Address. Co-operative Congress 1911, 29. Manchester: Co-operative Congress ... See also Neary and Winn, Co-operative university now!; Congress resolutions, Co-operative Congress 1910. Manchester: Co-operative Union. ${ }^{49}$ Macmillan, Margaret. 1911. Public meeting on education - future of our young people. Cooperative Congress 1911, 523. Manchester: Co-operative Union.

${ }^{50}$ Killon, Thomas. 1918. Inaugural address. Co-operative Congress 1918, 81. Manchester: Co-operative Union.

${ }^{51}$ Ibid., 84.

${ }^{52}$ Hall, Fred. 1919. Reply to Education Conference, Co-operative Congress 1919, 79. Manchester: Co-operative Union.

53 Alderman Hayward. 1919. Introduction to inaugural address. Co-operative Congress 1919, 94. Manchester: Co-operative Union.
} 
The College was probably the first specifically co-operative college in the world and would have a wide impact as other European countries established similar institutions during the interwar period, adding to the diversity of higher learning. Hall recognised that weekend and summer schools attracted a new 'type of person' who might also come to the College. A new curriculum was to link

our education more with everyday subjects, like co-operation in relation to reconstruction, social problems, politics, economics, internationalism etc. We want to give a knowledge, too, of the history of subjects and movements and theories to show how they have grown and changed, so that students know something about causes. On the other hand, we shall teach business organisation, commercial knowledge, cooperative and commercial law, management, salesmanship, and all that is necessary for the advancement of co-operative commerce on efficient lines. ${ }^{54}$

Propagating both focused co-operative education as well as engaging with broader knowledge and issues from a co-operative perspective, proved to be problematic yet indispensable. Attempts at educating in social science and vocational skills met obvious obstacles in terms of time available but it was to be an enduring aspect of College work. For example, the principal of the College during the post war years, Robert Marshall, felt that the residential aspect was conducive to the education of the 'whole man' via vocational learning. ${ }^{55}$

The College contributed to debates about relations with existing universities and the potential for a university of labour. Although it was expected that the College should be within 'Easy reach of an established University..., ${ }^{56}$ some co-operators felt that the movement was isolating itself from both labour and the universities. For instance, the remarkable growth of working class movements in the early twentieth century made it possible to think about forming a general workers' university. Lilian Dawson was critical of the 'tendency for each section of the Labour Movement to confine its educational work strictly within the limits of its own views ... this produced a limited outlook, some waste, and serious overlapping.' Co-

\footnotetext{
${ }^{54}$ H., J. 1919. The man of the month: professor F. Hall, M.A. The Producer, July 21, 226 article 225-6.

${ }^{55}$ Marshall, Robert. 1948. The Co-operative College. Adult Education. 20, 3: 131.

${ }^{56}$ Co-operative Union. 1944. The British Co-operative College: Through knowledge to service 1919-1944, 11. Manchester: Co-operative Union.
} 
operation, trade unions and the Labour Party should be bound together by common aims and ideals. She proposed a general educational council which would 'pave the way to the Labour University which every educationalist in the Labour Movement has in view as an ultimate achievement'. Dawson speculated that, in time, various elements of the labour movement might create 'one common Labour College... This association might at first take the form of interchange of students and lecturers and, where possible and desirable, joint courses. Eventually the college might be federated or affiliated in what would, in effect, be a Labour University. ${ }^{57}$ Co-operative education was too restrictive, according to Dawson, and she urged co-operators to connect with broader social and educational developments:

The Movement is an industrial system of a revolutionary kind when compared with the ordinary capitalist system. The Co-operative Commonwealth, which is its ultimate end, would imply a very drastic alteration in the whole constitution of society. The beliefs of the convinced co-operator, and his problems and the problems which in fact beset the Movement, wander very far afield and become entangled in questions which cannot possibly be included in a strict interpretation of 'the history and principles of co-operation'. If the Movement is to consist of members having the knowledge necessary for the understanding of these wider issues and problems - and if it does not, co-operation will become stagnant - it must give to its members the opportunity of acquiring such knowledge. Such education would touch not only political science, economics, sociology, but the whole science and art of citizenship, and must necessarily become involved in the dangerous ground of current controversial politics. ${ }^{58}$

This was a step too far for many co-operators who did not want to lose the benefits of having their own institutions. The all-encompassing perception of the co-operative commonwealth was not always in tune with the co-operative movement in the here and now. In any case, some of these distinctions were to be reformulated in the post war period by an expanding welfare state which changed the rules of the game for the co-operative movement.

${ }^{57}$ Dawson, Lillian. 1923. Co-operative education, 13-14. Manchester: Co-operative Union.

${ }^{58}$ Ibid., 12 


\section{Post war}

The Co-operative College was fortified after the Second World War with the purchase of a stately home, Stanford Hall, in Leicestershire. This was a symbolic moment of growth, a coming of age for the movement which saw itself as building a new Jerusalem. But, despite the general excitement about peace and the future, there was also a hardening of educational distinctions across the board which restricted the scope of the co-operative movement. For much of the post war period, the College provided education and training to managerial staff, co-operative secretaries, social studies students as well as future co-operative leaders from across the colonies and commonwealth. In total they numbered just over a hundred each year. Although it was conceived as a form of higher training, there was also an acceptance that the College was a 'residential adult education college' which occupied a separate role to universities.

Robert Marshall, the principal, exuded a mix of radical co-operativism and a conservative acceptance of the new status quo. At the 1948 Edinburgh Co-operative Congress, Marshall declared that he saw 'the objective of co-operative education as no less than that of educating the ruling class for the discharge of effective power. The ruling class to-day was the working and industrial class, and education should be given not only in social and political science but in business organisation and administrative training'. ${ }^{59}$ At a time when adult educators were debating the standards of adult education, he argued that the College should be a 'higher centre' of learning but, as principal, faced the internecine and complex politics of the consumer movement which made life difficult. Co-operative societies had to accept that they should not control who they sent to the College irrespective of educational capacity; they had to be willing to release students from their existing work; and also had to offer effective learning opportunities for College students. ${ }^{60}$ Such internal wrangling could act as a break on innovation.

In addition, the post war world would witness a prolonged period of decline in consumer cooperation, especially from the 1960s although the warning signs had been there for longer. ${ }^{61}$

\footnotetext{
${ }^{59}$ Marshall, Robert. 1948. Quoted in Co-operative Review, May 22, 5: 96.

${ }^{60}$ Marshall, Robert. 1947. Prospectus and prospects. Co-operative Review August, 21, 8: 162-3.

${ }^{61}$ For instance, Walton, John. 2009. The post war decline of the British retail co-operative movement: nature, causes and consequences. In Black, Lawrence and Robertson, Nicole, Consumerism and the co-operative movement in modern British history, 13-32. Manchester: Manchester University Press.
} 
One aspect of this was the way the movement could not adequately respond to the expansion of educational opportunities which provided escape routes for able working-class children. As a result, it became more inward looking and leaders held on to their positions as societies, which were struggling to survive. The co-operative educator faced a new predicament

Traditionally Co-operative Societies have recruited at the minimum school leaving age and relied on finding within such recruitment the quality which would later show itself capable of management responsibilities. Now, however, much of the ability which 30 years ago would have left school at 14 and come into Co-operative service is going on to grammar schools and to Universities and if we want to attract that ability we have to look for it there. ${ }^{62}$

The idea of educating your own leaders within a democratic movement began to appear archaic. This was a significant cultural shift for co-operators who were unfamiliar with having to catch up with the commercial world. In addition, the recruitment needs of cooperatives lent some credence to widespread beliefs in a 'pool of ability' and could set in motion the talking down of potential of co-operative members and working class people in general. Interestingly, Marshall was guarded about plans for an Open University and he questioned the views of Hilary Perraton who had argued that the new university of the air would be relevant to everyone. By contrast, Marshall was sceptical

If this means anything, it must be that everyone is capable of engaging with study of a University quality - and frankly I do not think this is true. It is no discredit to anyone to say that he or she is not capable of study of that quality, but a simple acknowledgement of the human condition. ${ }^{63}$

Marshall was out of touch with the times when comprehensive education and ideas of equal educability were making ground. ${ }^{64}$ Thus, while the gains of a post war new Jerusalem had involved the diminution of the co-operative sphere of activity within the social and economic

\footnotetext{
${ }^{62}$ Marshall, Robert. 1967. Draft (not in final version) for Management development scheme. In Trends in the services for youth, eds. Farndale, W. A. J. and Leicester, James A. Oxford: Pergamon. Bishopsgate Institute, Robert Marshall papers, box 2. ${ }^{63}$ Marshall, Robert. 1968? An open question? A note on the "Open University... Bishopsgate Institute. Robert Marshall Archive. Articles written by the principal, January 1960- Box 2, folder 2, articles written by the principal, January 1957-December 1968.

${ }^{64}$ For instance, Simon, Brian. 1953. Intelligence testing and the comprehensive school. London: Lawrence and Wishart.
} 
settlement, co-operators continued to make radical claims for economic democracy and the flame of the co-operative commonwealth was not extinguished.

\section{Managing futures}

The engagement of co-operators with higher education has been a continuous process of asserting rights of access, developing separate provision, fostering mutual learning and reworking educational relationships. A deep educational yearning and a desire for social change stretched back to Owenism and the Rochdale Pioneers. Building an economic system on co-operative principles required an awareness of the alternative futures that their work implied as well as the skills to start working towards it. The co-existence of practical action to sustain an economic enterprise and utopian democratic visions fuelled critiques of the university at moments when new possibilities flared up in the co-operative imagination. In turn, the material growth of the movement provided a foundation for democratic ideals which extended to higher education, among co-operators and beyond.

Co-operative encounters with the university have both challenged and reproduced hierarchies and divisions - between co-operatives and other adult education movements and between universities and adult education. Class, gender and race inequalities have been implicit in these debates. In terms of curriculum, co-operatives valued both liberal and vocational forms of learning which to some extent set them apart from the humanistic tradition of adult education in Britain. A distinctive co-operative curriculum gave strength and purpose to the movement but also isolated it from adult and university education which tended to shun vocational learning. At different times, co-operators advocated vocational education, liberal learning and learning for social change as three streams that flowed together and diverged at different times. ${ }^{65}$

Co-operators saw themselves as very practical people who were chary of theory and knowledge that was not immediately useful. This could limit experimentation. A general inertia among some co-operators, as well as practical obstacles, prevented the expansion of initiatives. There was a continuing body of co-operators who did not particularly see the movement as an educational force although these tended to be the least active members. The

${ }^{65}$ Woodin, Tom. 2019 forthcoming. Recovering co-operative education. In Woodin, Tom and Shaw, Linda. Learning for a co-operative world: education, social change and the Cooperative College. London: Trentham/UCL Press. 
embrace of the university was also replete with danger, that co-operators might be diverted from their core purpose and become allied to other purposes. For this reason, they defended their independence. Moreover, keeping the idea of a co-operative university alive has not been a continuous process and educational traditions could wane. For example, a contributor to the Co-operative Review in 1936 felt that there existed a 'prejudice' against universities and proposed that societies should make themselves amenable to university extension lectures, apparently unaware that the historical ties between the two movements appeared to had been severed. ${ }^{66}$

However, traditions are rarely extinguished entirely; rather they resurface sporadically in new contexts. The dilemmas surrounding previous attempts to construct co-operative higher education have a contemporary echo. The nascent co-operative university in 2019 is attempting to rethink the nature of the university and manage contradictions which have a long historical pedigree. There is a desire to fill the space that has been left in wake of the decimation of adult education over the past few decades. Campaign groups have emerged after losing funding and constituencies have formed around educational, environmental and political purposes; each of them has found expression in the proposals for a co-operative university. ${ }^{67}$ The desire for practical learning, as part of co-operative and social movements, is one area which could be fruitfully developed, comprising both research and teaching. Indeed, the new university will want to contribute to existing co-operative movements while initiating original research. Constructing coherent and sustainable degree programs from the ground up will pose a further challenge. In establishing a university, the numbers have to add up and providing distinctive courses will depend upon recruiting an adequate number of students, not least from within the ranks of the co-operative movement. Standards and quality are likely to be perennial items for discussion as are the competing claims of vocational learning, liberal education and directly fostering social change. Managing these tensions and experimenting with democratic forms raises the possibility of constructing new co-operative futures that build upon historical traditions.

\footnotetext{
${ }^{66}$ Anon. 1936. Co-operative Review October 10, 10: 313.

${ }^{67}$ Neary and Winn, Co-operative university now!
} 